\title{
Hemorrhagic bullous henoch schonlein purpura: a diagnostic challenge for paediatricians
}

\section{TS Trapani ${ }^{1}$, MP Mariotti ${ }^{2}$, RM Resti ${ }^{1}$, DMM de Martino ${ }^{1}$ and FF Falcini ${ }^{* 1}$}

Address: ${ }^{1}$ Department of Paediatrics, University of Florence, Anna Meyer Children's Hospital, Florence, Italy and ${ }^{2}$ Division of Paediatrics, Hospital of Pistoia, Pistoia, Italy

* Corresponding author

from I5th Paediatric Rheumatology European Society (PreS) Congress

London, UK. 14-17 September 2008

Published: 15 September 2008

Pediatric Rheumatology 2008, 6(Suppl I):P27| doi:I0.I I86/I546-0096-6-SI-P27 I

This abstract is available from: http://www.ped-rheum.com/content/6/SI/P27I

(c) 2008 Trapani et al; licensee BioMed Central Ltd.

\section{Background}

Hemorragic bullous lesions have been noticed in 16\%$60 \%$ of adults and in $2 \%$ of children with HSP. This unusual cutaneous manifestation may cause diagnostic challenge. We report two new paediatric cases.

\section{Patients}

A 9-year-old girl and 11-year-old boy were admitted to our hospital with abdominal pain, arthralgia, ecchymoses and petechiae at legs, arms and buttocks. Shortly, large, tense hemorrhagic bullae and vesicles ( 2 to $30 \mathrm{~mm}$ ) developed over the purpuric rash, while petechiae spreaded over face and neck. Both patients were prostrate and drowsy with a diffuse oedema of periorbital region, hands and feet. Laboratory tests showed increased CRP $5.2 \mathrm{mg} /$ $\mathrm{dl}$, WBC $23 \times 10^{9} / \mathrm{L}$ and PTL $623 \times 10^{9} / \mathrm{L}$. Serological investigation for viruses (Epstein Barr Virus, Cytomegalovirus, and Hepatitis-C Virus) and bacteria were negative. ANA, pANCA, cANCA absent. Urinalysis showed proteinuria $(1 \mathrm{~g} / 24 \mathrm{~h})$ and hematuria (1074 red blood cells/ field) in the girl. Cardiologic evaluation, lung X-ray, and abdominal ultrasound were unremarkable. Due to an aggressive infection of the cutaneous lesions, imipemen and teicoplanine were introduced. Three pulses of methylprednisolone were given to the girl, and then oral prednisone $(2 \mathrm{mg} / \mathrm{kg} /$ daily) to control renal disease. Bullae faded within the next two weeks and necrotic lesions healed leaving a mild pigmentation and scars.

\section{Conclusion}

In childhood HSP the occurrence of hemorrhagic bullae may be a diagnostic challenge at onset in absence of other typical symptoms as many paediatric diseases including toxic epidermal necrolisis, erythema multiform, pemphigus, bullous impetigo, dermatitis herpetiformis and staphylococcal scalded skin syndrome may present with bullous cutaneous lesions. 